\title{
LIQUID EXTRACTION OF SUBSTRATE FROM MANURE FOR EFFICIENT BIOGAS PRODUCTION
}

\author{
Harald Stjernholm \\ Carlos Dinamarca \\ Deshai Botheju \\ Rune Bakke \\ Telemark University College, Norway
}

\begin{abstract}
In search for both new renewable energy and an effective way to reduce emission of greenhouse gases from farming, anaerobic digestion that produces methane is now considered the most efficient process.

The main challenge in implementing this process in typical small- to medium-scale farming is the relatively large investments necessary compared to the economic benefits achieved. Transport of manure through pipes, tanks, reactors and settling tanks all add up to a cost higher than the economic benefits for the farm. A way of reducing these costs by simplifying the process is analysed here. Drainage of liquids from existing storage facilities both reduces the necessary amount of construction and of the reactor volume for biogas production. The drained substrate liquid from the storage is fed a high efficiency biogas reactor. The reactor outlet is returned to the manure storage tank.

The test necessary to quantify the achievable amounts of drained liquid was done using a $3.4 \mathrm{~m}^{3}$ vessel, containing slightly diluted cow manure (14\% diluted). A $1.4 \mathrm{~m}$ long common corrugated drainpipe $(80 / 100 \mathrm{~mm})$ was used for drainage. This was wrapped in common mosquito net in order to avoid clogging and increase the area of filtration. For observation of scaling effects, a small lab scale feeder, (1:1000 regarding the vessel, the scaling of the filter area is $1: 17.5$ ) with a subsequent reactor was used in addition. In both cases peristaltic pumps were used to assure the necessary flow accuracy and provide a vacuum suction of 0.1 bar. Maximum flux of drained liquid achieved though the drainpipe was $341 \mathrm{~L} / \mathrm{m}^{2}$.d in the pilot vessel and $48 \mathrm{~L} / \mathrm{m}^{2} . \mathrm{d}$ in lab scale, implying that the proposed biogas process based on liquid feed extraction from manure is feasible.
\end{abstract}

\section{KEYWORDS}

Biogas; Liquid Extraction; Manure; UASB reactor.

\section{INTRODUCTION}

Agricultural activities worldwide, is a huge contributor of emissions of climatic gases into our atmosphere [1]. In Norway, for example, farming is responsible for more than $9 \%$ of total greenhouse gas emissions [2], mostly from manure. The best way of reducing these emissions and at the same time utilize its valuable potentials as energy, is by anaerobic digestion [3]. A main obstacle that discourages farmers from biogas production is the high investment 
required. Many farmers have installed biogas reactors, with varying success, in countries such as Germany with heavy subsidies of biogas projects. Only one large plant is in operation in Norway due to lack of subsidies. High investments in large volume pipes, tanks, reactors and pumps all add up to a capital cost higher than the economic benefits of biogas production and improved fertilizer quality for the farm.

Our main goal is to find effective ways of reducing the costs of construction and operation of farm scale biogas processes. The financial cost is cut by applying high efficiency biogas reactors, thereby downsizing all components necessary, like tanks, pumps, piping and insulation. Particles need to be removed from the feed for such high rate biogas reactors to function properly. A submersible drain pipe filter for this purpose is proposed and previously tested on apple waste [4]. This filtration is the new process step in the proposed farm biogas concept, and, therefore, demands more in depth analysis to determine design criteria. The aim of this study is to determine the filtration efficiency of cow manure by the proposed drain pipe technique.

\section{METHODS}

Standard corrugated drainpipe $(80 / 100 \mathrm{~mm})$ wrapped in $1 \mathrm{~mm}$ mesh mosquito net was used for drainage of cow manure (Figure 1). The manure was diluted $14 \%$ with water.

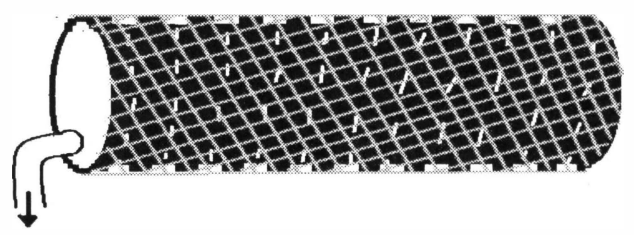

Figure 1. Sketch of drainpipe wrapped in mosquito net.

The flux of liquid through the drainpipe wrapped in net was tested in two scales: 1) Pilot scale; a $1.4 \mathrm{~m}$ long pipe in a $3.4 \mathrm{~m}^{3}$ vessel. 2) Lab. Scale; $0.1 \mathrm{~m}$ pipe in a $2 \mathrm{~L}$ vessel (Figure 2). A subsequent biogas reactor was used in both cases, with peristaltic pumps to maintain flow and provide a vacuum suction of up to 0.1 bar. The amount of liquid draining was regulated by the pump. The largest liquid volume that could be delivered for several days was assumed to represent the maximum flux. The drain flux was determined as the flow divided by the drainpipe surface area.

Three $1.4 \mathrm{~m}$ of drainpipes were installed in the $3.4 \mathrm{~m}^{3}$ vessel at 3 different levels varying from 0.3 to $1.3 \mathrm{~m}$ depth to investigate the influence of liquid pressure on the flux without applying any vacuum. This test was performed first to choose one of the pipes for the rest of the experiments. 


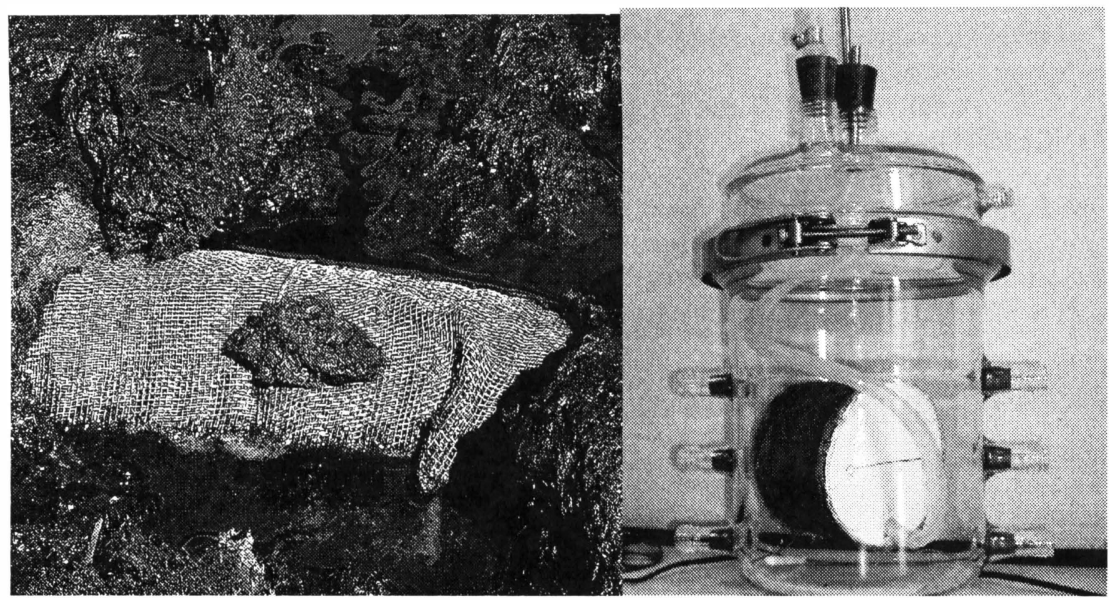

Figure 2. a) Drainpipe submerged in manure in $3.4 \mathrm{~m}^{3}$ vessel (left). b) Laboratory scale apparatus (right).

\section{RESULTS}

The flux increased linearly with depth, implying that pressure has a dominating effect on the flux, and that gravimetrical conditions, like sedimentation and flotation, is of minor significance in this experiment. The bottom drainpipe was, therefore, chosen for the following suction experiments.

Maximum flux of liquid though the drainpipe achieved was $341 \mathrm{~L} / \mathrm{m}^{2} . \mathrm{d}$ in the pilot vessel and $48 \mathrm{~L} / \mathrm{m}^{2}$.d in lab scale. The build up of a permeable filter cake of more than $10 \mathrm{~mm}$ on the mosquito net was observed. This filter cake apparently removed particles much smaller than the actual filter mesh of the mosquito net, while maintaining satisfactory drainage.

The drained liquid has a composition $(20 \mathrm{~g} \mathrm{COD} / \mathrm{L}$ and $\mathrm{pH}=7.9)$ suitable for high rate biogas processes.

\section{DISCUSSIONS}

High efficiency biogas reactors, such as the UASB, are much less sensitive to temperature than traditional processes [5]. Less investments in temperature control and less energy for process heating is therefore required when a suitable liquid feed is obtained. Reduced cost of construction and operation can thereby be obtained by the tested drain system.

The drain method also has a buffer effect maintaining relatively stable feed, reducing the chance of biogas process overload. This is especially important if additional wastes are added to the manure storage to enhance biogas production.

Due to the results obtained and presented here, and the ever increasing demand for sane environmental solutions, a full scale biogas plant, utilizing the manure from 60 milk cows, is planned. This plant is intended as a demonstration and research facility, designed to further 
test the drain technique and how it can integrated in a standardized complete concept for farm scale energy recovery.

\section{CONCLUSIONS}

Liquid drained from cow manure storage has low particle content, $\mathrm{pH}=7.9$ and high soluble organic content $(20 \mathrm{~g} \mathrm{COD} / \mathrm{L})$, and is suitable as feed for high rate biogas reactors. The low cost drain technique obtained a flux of $341 \mathrm{~L} / \mathrm{m}^{2} . \mathrm{d}$ in a pilot scale test. This flux is high enough to make this technique feasible for full scale plants.

These results suggest that cost effective farm scale biogas plants, consisting of a filter to drain a low particle liquid feed from existing manure storage and a high rate biogas reactor, can be designed.

\section{ACKNOWLEDGEMENTS}

Authors acknowledge the contributions to this research from the Norwegian National Science Foundation, the Norwegian Department of Agriculture, the farmer Knut Vasdal, constructor of pilot plant Terje Baardseng and the technical staff in university laboratories.

\section{REFERENCES}

[9] Inst.S.nr 285, 2006-2007. Instilling fra näringskomiteen om jordbruksoppgjöret 2007endrinder i statsbudsjettet for 2007.

[10] Statistisk sentralbyrå. Utslipp av klimagasser 1990-2005 www.ssb.no/emner/01/04/10/klimagassn/arkiv/art-2007-02-12-01.html

[11] SFT, Norwegian Polution Control Authority, 2007. Reduksjoner av klimagasser i Norge- en tiltaksanalyse for 2020. 17-18. ISBN 978-82-7655-514-1

[12] Chen, Z., Bakke, R., Dinamarca, C., Wenjun, W., 2007. A simple two-stage anaerobic digestion process consisting of a leach-bed and a biogas reactor used for treating agricultural organic waste.

[5] Mohn, I., Siversson, B., Batstone, B., Björnsson, L., Mattiasson, B., 2006. Anaerobic digestion of agricultural residues under psychrophilic conditions. 